\title{
Solução de problemas e tomadas de decisão em reuniões empresariais
}

\author{
Problem-solving and decision-making in business meetings \\ Clarissa Rollin Pinheiro BASTOS* \\ Pontifícia Universidade Católica do Rio de Janeiro (PUC-Rio)
}

\begin{abstract}
RESUMO: O presente trabalho objetiva contribuir para uma melhor compreensão da coconstrução discursiva de atividades de fala problema-solução e tomadas de decisão, considerando a ordem interacional, no contexto de três reuniões empresariais em uma empresa brasileira da construção civil, estabelecida na cidade do Rio de Janeiro. Executivos, funcionários e representantes comerciais de vendas participam das reuniões. Os resultados parecem ser extremamente significativos quando focalizamos as ações comunicativas realizadas pelos participantes: (1) as variáveis contextuais apontam para diferentes estruturas problema-solução; (2) cada fase prevista no modelo se constitui como um "território" de participação, embora não exclusivo; (3) a organização hierárquica da empresa pertencente à macro-ordem social se reflete na micro-ordem de participação.
\end{abstract}

PALAVRAS-CHAVE: Linguagem e trabalho. Solução de problemas. Tomadas de decisão. Reunião empresarial.

ABSTRACT: The present work aims at contributing to a better understanding of the coconstruction of problem-solving speech activities and decision making, considering the interactional order, in the context of three multiparticipative business meetings in a Brazilian civil construction entrepreneurship, established in the Rio de Janeiro city. Executives, employees and commercial sales representatives took part in the meetings. The findings appeared to be extremely meaningful when we focus on the communicative actions carried out by the participants: (1) the context variables point toward different problem-solving structures; (2) each phase previewed in the model is constituted as a participation "territory", although it is not considered exclusive; (3) the company's hierarchical organization belonging to the macro order reflects itself through the participation structure in the micro order.

KEYWORDS: Language and work. Problem-solving. Decision-making. Business meeting

\section{Introdução}

As novas realidades sócio-político-econômicas vêm acarretando grandes transformações, que apontam significativamente para a importância do compartilhamento das informações para a solução de problemas e tomadas de decisão no contexto do trabalho. A palavra, antes interdita no trabalho, embora se saiba que a colaboração com outros seja central à atividade humana, tem sido contemporaneamente mais requerida, uma situação que demanda uma maior compreensão.

\footnotetext{
* Doutorado em Letras, área de Estudos da Linguagem; professora Adjunta da Pontifícia Universidade Católica do Rio de Janeiro (PUC-RJ), Departamento de Letras. Rio de Janeiro - RJ - Brasil. E-mail: clarissabastos@puc-rio.br.
} 
Ainda que os profissionais possam ser chamados a contribuir em diferentes graus, espera-se um maior engajamento dos colaboradores, o que pode resultar em um interessante trabalho de reflexão e contribuição conjunta, percebido como central à legitimação da instituição e, por extensão, à sua manutenção.

Grande parte das práticas de trabalho ocorre em torno de como os problemas são resolvidos e decisões são tomadas, ou seja, são atividades recorrentes, que, junto a outras, fazem do local de trabalho um ambiente discursivo distinto. Difíceis de capturar no cotidiano do trabalho, sua dispersão e fragmentação devem-se não apenas ao tipo de instituição, mas também aos aspectos contingenciais dessas atividades (KUHN; JACKSON, 2008; SARANGI; ROBERTS, 1999). Assim, quando profissionais de uma dada organização encontram-se, por exemplo, em reuniões, que se propõem a uma ampla avaliação do trabalho que realizam, essa prática pode ser vista como ideal à observação e à análise do processo de solução de problemas e tomadas de decisão.

Este artigo apresenta um estudo da construção discursiva coletiva de atividades de fala orientadas para a solução de problemas e tomadas de decisão em reuniões empresariais realizadas em uma empresa brasileira da construção civil, das quais participam gestores, funcionários e prestadores de serviço. Trata-se de uma empresa atacadista, estabelecida no Rio de Janeiro há trinta anos, cuja atividade principal consiste na comercialização de materiais de construção.

Reuniões empresariais, de acordo com Boden (1994), representam a ordem interacional do gerenciamento, a arena da atividade organizacional para a ação gerencial. Permanecem como mecanismo essencial através do qual as organizações se revisam e se mantêm, representando um meio ótimo para transmitir e disseminar informações e políticas, garantir o fluxo comunicacional, melhorar a comunicação entre os setores da empresa, e ainda efetivar o controle organizacional.

Reuniões, organizadas com base em uma agenda prévia ou não, são construídas pelos profissionais que participam do encontro. Esses contribuem com sua experiência e seu conhecimento especializado, necessários para a condução dos negócios, renovação e manutenção das organizações (LUHMMAN, 1990 apud SARANGI; ROBERTS, 1999; BODEN, 1994). Com base em seus esquemas de conhecimento, os profissionais enquadram o que está acontecendo e constroem significados expressos na forma em que conduzem a produção ou a recepção de um enunciado (GOFFMAN, 1981; GUMPERZ, 1982; TANNEN; WALLAT, 1987).

No presente trabalho, focalizo atividades de fala orientadas para a solução de problemas e tomadas de decisão construídas no trabalho discursivo e interacional dos profissionais que participaram de três reuniões de trabalho na Ramo Ferro Ltda. (na Seção 3 , apresento o contexto da pesquisa). Procuro observar a distribuição do trabalho social e linguístico dos participantes na co-construção dessas atividades, bem como os indivíduos regulam e regularizam as relações institucionais, envolvidas na produção do conhecimento e na solução de problemas e na manutenção da ordem institucional.

Além da proposta de articulação entre a área dos estudos do discurso na vertente da Sociolinguística Interacional em interface com a Análise da Conversa, pretendo trazer contribuições dos estudos linguísticos relacionados ao processo de solução de problemas e tomadas de decisão, especificamente em reuniões empresariais, bem como contribuir para a compreensão do uso do discurso em práticas partilhadas na empresa no contexto brasileiro. 


\section{Sobre solução de problemas e tomadas de decisão em locais de trabalho}

Geralmente abordadas por modelos cognitivos na literatura, solução de problemas e tomadas de decisão necessitam ser examinadas no processo interacional, na própria atividade de trabalho, como sugere Boden (1994). No entanto, a ideia de que essas são atividades claramente definidas e próprias de uma interação específica é inviável. Solução de problemas e decisões não são tópicos, emergem de uma série de atividades e contextos, e é difícil definir o momento da conversa em que a decisão é tomada, constituindo-se, assim, uma instigante área de investigação para os interessados nessa questão.

A organização discursiva problema-solução tem sido contemplada por estudos voltados para atividades de consulta, mediadas por computador (PATTHEY-CHAVEZ, 1994) ou realizadas face a face (PEREIRA, 1996), e de estudos voltados para atividades de negociação com foco na solução de problemas técnicos, via conversação telefônica e textos escritos (fax) (WAGNER, 1995), e ainda tem sido foco de atenção de estudos que investigam padrões problema-solução junto a outros objetivos (HOEY, 1986, BELMONTE, 2009).

Patthey-Chavez (1994), a partir de estudo realizado em laboratório computacional sobre práticas consultivas por e-mail, propõe uma estrutura das fases da atividade de consulta, considerando também a estrutura de participação. Pereira (1996), em estudo sobre interações de ajuda face a face em um serviço de atendimento ao cliente em uma empresa brasileira, adverte que, embora haja uma proposição geral para as atividades de consulta, cada tipo de atividade tem a sua própria natureza.

Uma vez iniciadas, as atividades de consulta e de solução de problema desenvolvem uma sequência de fases ou movimentos que resultam numa estrutura prototípica para solução de problemas, apresentada a seguir:

Quadro 1 - Estrutura prototípica problema-solução

\begin{tabular}{|l|l|}
\hline \multicolumn{1}{|c|}{ Fases da atividade } & \multicolumn{1}{c|}{ Estrutura de participação } \\
\hline 1. Comunicação do problema & Dominância do cliente \\
2. Diagnose do problema & Mudança de cliente para consultor \\
3. Proposta de solução & Dominância do consultor \\
4. Implementação da solução & União conversacional entre consultor e cliente \\
\hline
\end{tabular}

(FONTE: PATTHEY-CHAVEZ, 1994, p. 85)

Patthey-Chavez (1994) observa que, à medida que a atividade progride de uma fase a outra, da apresentação do problema à implementação da solução, há uma mudança na estrutura de participação - do cliente para o consultor como articulador principal, seguindo uma mudança em direção a uma união cognitiva e conversacional através das quais a solução do problema é alcançada.

Pereira (1996) observa que, durante as atividades de consulta, há modificações na estrutura de participação e nos enquadres das atividades, que oscilam entre a atendente e o cliente e variam entre o enquadre profissional e o enquadre pessoal.

Wagner (1995) analisa atividades de negociação sob duas perspectivas: a primeira procura captar a organização sequencial da interação em um procedimento para resolução de problemas técnicos; a segunda baseia-se no conceito de "atividades de negociação", de Firth (1991 apud WAGNER, 1995, p. 224). 
Considerando a organização sequencial da interação, com base em um caso apresentado, o autor propõe, como um modelo possível, a seguinte sequência de passos na resolução do problema:

1. uma das partes propõe a existência de um problema técnico; a outra parte aceita a existência do problema;

2. uma parte propõe uma solução; a outra parte aceita que a proposta é válida;

3. ambas as partes aceitam a proposta como solução;

4. a solução é implementada.

A partir do conceito de "atividade de negociação", o autor mostra como esse tipo de atividade é usado para iniciar atividades de solução de problemas. Wagner (1995) observa, em dois outros casos analisados, variações em relação ao modelo proposto acima, terminando por dizer que este não pode ser generalizado para todos os casos de solução de problemas. $\mathrm{O}$ autor conclui que, para se resolver um problema, os participantes têm que realizar certas ações: (a) concordar que há um problema e (b) encontrar uma solução e implementá-la. Ainda afirma que os participantes têm que interagir sobre certos tópicos e não, necessariamente, concordar sobre o problema. Tem-se, portanto, que a decisão deriva da aceitação de uma proposta de solução.

Hoey (1986) faz uma revisão de modos através dos quais é possível identificar padrões de organização discursiva, principalmente relacionados a textos escritos. $\mathrm{O}$ autor procura mapear as condições que permitem mostrar de um modo regular as relações que constituem o padrão, lembrando que "descrever um padrão é descrever as relações através das quais ele surge" (HOEY, 1986, p.190). Considerando os envolvidos na situação, Hoye acaba por propor a seguinte fórmula:

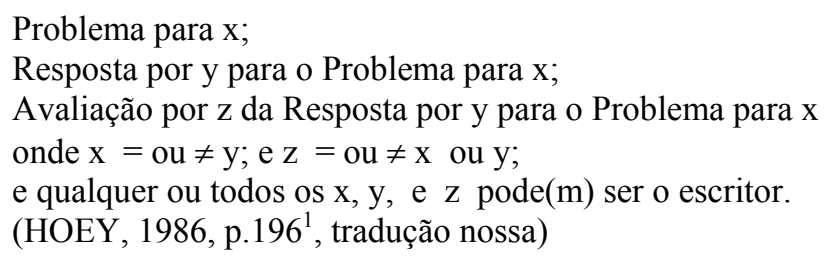

Para Belmonte (2009), o padrão problema-solução em editoriais e artigos opinativos jornalísticos forma uma complexa rede de sequências funcionalmente organizadas e inter-relacionadas, cuja ordem canônica - problema - avaliação/diagnóstico - solução - pode ser propositadamente subvertida em função de objetivos enfáticos.

Esses estudos fornecem elementos para a análise das atividades de fala orientadas para a solução de problemas e tomadas de decisão no que se refere à organização discursiva sequencial e/ou dinâmica da atividade em reuniões empresariais de multiparticipação. Considerando o modelo prototípico apresentado por Patthey-Chavez (1994), é possível a priori propor a $4^{\mathrm{a}}$. fase como uma ação dos participantes que visa ao comprometimento com a implementação da solução, ou seja, uma decisão tomada, uma vez que este estudo privilegia interações orais em reuniões e, por isso, a implementação da solução não pode ser observada. Geralmente, associadas a essa fase, decisões podem emergir ao longo do processo de solução de problemas (BASTOS, 2001).

\footnotetext{
${ }^{1}$ Problem for $\mathrm{x}$; Response by $\mathrm{y}$ to Problem for $\mathrm{x}$; Evaluation by $\mathrm{z}$ of Response by $\mathrm{y}$ to Problem for $\mathrm{x}$; where $\mathrm{x}$ $=$ or $\neq \mathrm{y}$; and $\mathrm{z}=$ or $\neq \mathrm{x}$ or $\mathrm{y}$; and any or all of $\mathrm{x}, \mathrm{y}, \mathrm{z}$, and may be the writer.
} 


\section{As reuniões de trabalho na Ramo Ferro Ltda²}

As três reuniões selecionadas para a presente reflexão ocorreram na Ramo Ferro Ltda., empresa brasileira, atacadista, estabelecida no Rio de Janeiro há 30 anos, cuja atividade principal consiste na comercialização de materiais de construção para o comércio varejista.

Foram realizadas com o pessoal da área de vendas, num total de 8 horas de gravação, tendo sido solicitadas e marcadas pelo Gerente de Vendas. O que motivou as reuniões foi a necessidade de se fazer uma avaliação das atividades, contemplando não apenas os resultados alcançados, como também problemas do dia-a-dia vividos pelas equipe de vendas. Cabe esclarecer que a empresa encontrava-se em processo de mudança havia mudado recentemente a sua locação e estava em processo de informatização.

Devido à natureza das reuniões, que se propõem, entre outros objetivos, a fazer uma ampla avaliação das atividades de vendas em que são consideradas não apenas o desempenho das funcionárias do setor de televendas e dos representantes de vendas, mas também os problemas internos e externos à empresa que interferem na produtividade, são construídas atividades de fala orientadas para a solução de problemas

A primeira reunião teve por objetivo avaliar o Projeto de Televendas. Dela participaram: o Gerente de Vendas, Nilson; o Diretor Administrativo, Jota; o Diretor Geral, Tom; e três operadoras de televendas - Sue, Joe e Isa. A agenda da reunião de Televendas foi assim definida: eliminação de dúvidas, estratégias de vendas, análise do desempenho e sistema de premiação. As operadoras sentaram-se em torno de uma mesa circular e o Gerente de Vendas ficou de pé, próximo ao flip-chart. O Diretor Administrativo entrou na sala cerca de 20 minutos após o seu início, sentando-se à mesa. O Diretor Geral, não convocado, também participou da reunião. Entrou na sala cerca de três minutos após a entrada do Diretor Administrativo, sentando-se em uma cadeira fora do círculo.

As duas reuniões com os representantes comerciais (RC), aqui denominadas reunião com representantes comerciais 1 e $2(\mathrm{RC} 1$ e 2$)$, tiveram como objetivo promover uma avaliação das atividades de vendas. Foram realizadas em uma sala de aula da empresa. A reunião 1 contou com a participação do Diretor Geral, do Diretor Administrativo, do Gerente de Vendas e de sete representantes comerciais. As cadeiras estavam arrumadas em fila, de modo tradicional. Na reunião 2, além dos dois diretores e do gerente, participaram oito representantes comerciais. Dessa vez, as cadeiras foram organizadas em U. O desenvolvimento dessas reuniões obedeceu às agendas estabelecidas, sendo que a agenda da primeira reunião não foi exposta oficialmente.

As reuniões 1 e 2 ocorreram, basicamente, em torno das atividades programadas, da seguinte forma: (a) apresentação pelos RCs das respostas dadas a um questionário de pesquisa elaborado pelo Gerente de Vendas e distribuído previamente aos participantes; (b) análise da carteira de clientes de cada representante comercial.

Como as perguntas do questionário eram as mesmas para todos os representantes, foi-lhes solicitado que, se houvesse repetição nas respostas, elas deveriam ser omitidas. Essa medida tinha o caráter de agilizar a reunião, porém impediu os participantes de terem a visão global da reincidência de aspectos em relação a qualquer questão. Tomamos para análise as respostas dos RCs à pergunta: "Na sua opinião, o que a empresa precisa fazer para ajudá-lo a vender mais? Mencione apenas os motivos relacionados à empresa."

\footnotetext{
2 Os nomes das empresas citadas bem como dos profissionais colaboradores são todos fictícios. Foram mantidos os nomes dos produtos mencionados.
} 
Devido aos objetivos estabelecidos para as reuniões, são construídas as atividades de fala orientadas para a solução de problemas ainda pouco estudadas em interações orais, o que possibilita uma contribuição deste trabalho para que se conheça o processo de solução de problemas e tomadas de decisão em reuniões de trabalho.

A metodologia de pesquisa deste estudo é de base etnográfica (HYMES, 1974; 1977, ERICKSON; SCHULTZ, 2002), mediante observação participante, gravação em áudio e notas de campo. O corpus de estudo do qual deriva a seleção das reuniões aqui focalizadas originam-se de $20 \mathrm{~h}$ de gravação de reuniões geradas no percurso de um ano e meio de pesquisa. $\mathrm{O}$ estudo se desenvolve na perspectiva sociointeracional para a análise do discurso (GOFFMAN, 1981; GUMPERZ, 1982; SCHIFFRIN, 1996, entre outros) em interface com a Análise da Conversa (SACKS, SCHEGLOFF; JEFFERSON, 1974). Nessa abordagem, o discurso é concebido como o resultado da produção conjunta dos participantes da interação, em que os significados são construídos e negociados, a partir da compreensão sobre o que acontece e dos propósitos do encontro.

\section{Análise}

$\mathrm{Na}$ análise das reuniões, observei a organização de quatorze atividades de fala problema: cinco na reunião de televendas; cinco na primeira reunião com representantes de vendas e quatro na segunda reunião também com representantes de vendas. Julgo, assim, que esse conjunto de dados reúne condições exemplares para o trabalho aqui proposto.

Para a análise que se segue, selecionei três atividades de fala problema-solução, uma de cada encontro, construídas discursivamente na interação por vários profissionais. Nos segmentos selecionados, procuro identificar a organização global das atividades de fala problema-solução, com base no modelo proposto por Patthey-Chavez (1994) e capturar as variações que aí ocorrem, observando a organização das informações no dinamismo da sequência conversacional, as ações comunicativas e a produção de sentido, levando-se em conta, portanto, as pistas de contextualização (GUMPERZ, 1982).

Esse modelo prevê, como dito anteriormente, quatro fases, sendo que a última foi modificada por mim: comunicação do problema, diagnóstico, proposta de solução e compromisso com a implementação da solução (BASTOS, 2001) em vez de implementação da solução. Compreende, também, o quadro de participação nas fases de desenvolvimento da atividade.

$\mathrm{Na}$ identificação no quadro de participação em relação às fases da atividade, utilizarei o termo alternância para me referir à alocação de turno do coordenador para os participantes, considerados falantes principais; empregarei o termo multiparticipação para me referir à participação de vários falantes na co-construção de significados e usarei o termo dominância, significando padrões de assimetria manifestos no diálogo. ${ }^{3}$

\footnotetext{
3 Linnel e Luckman (1991, p.9) propõem a distinção entre quatro tipos de dominância: (a) dominância quantitativa, que diz respeito à relação entre as partes em termos de quantidade de fala, medida simplesmente em termos de número de palavras faladas; (b) dominância interacional, que se relaciona à distribuição de movimentos interacionais, isto é, ao gerenciamento da sequência e do formato do turno; (c) dominância semântica, que caracterizaria a pessoa como dominante se ele ou ela determinou os tópicos mantidos em um discurso e impõe perspectivas interpretativas sobre o que se diz; (d) dominância estratégica, que diz respeito a contribuir com as intervenções mais importantes estrategicamente, na medida que envolve avaliar retrospectivamente os resultados de toda a interação, incluindo alguns efeitos de maior ou menor durabilidade, extensão ou impacto. Não me proponho nesta reflexão, entretanto, a categorizar os tipos de dominância que ocorrem na estrutura de participação. Estarei somente indicando o participante dominante na sequência interacional.
} 
Examinar como essas atividades de fala se desenvolvem e a negociação e a distribuição das responsabilidades na sua construção significa olhar a divisão e a realização do trabalho através da linguagem como prática social na instituição.

As atividades de fala orientadas para a solução de problemas se iniciam quando um tópico é apresentado, que implica, de algum modo, uma dificuldade para atingir os objetivos institucionais - o problema - e, em relação ao qual há uma necessidade percebida de se apresentar uma resposta avaliativa, dar informações e explicações sobre fatos e/ou oferecer soluções ou orientações para o problema.

Problema pode ser definido como um aspecto da situação que requer uma solução (HOEY, 1994, p.30). Problema pode ser também definido como um obstáculo ou desvio que impede a boa realização dos negócios da empresa, entendendo-se obstáculo como algo que obstrui, e desvio como algo que não era suposto ocorrer. Problemas, ainda, podem ser causados pela estrutura da empresa, por procedimentos internos, por fatores tecnológicos e, ainda, por pessoas que, por exemplo, assumem um comportamento não desejável (LIMA; TEIXEIRA, 2000, p. 56). Passemos, então, às cenas interacionais.

\subsection{Problema 1 - Faturamento}

O primeiro problema apresentado - Faturamento - ocorre na Reunião 1 com representantes comerciais. Dessa reunião participaram 10 profissionais: 7 representantes comerciais; o gerente de vendas, Nilson; o diretor administrativo, Jota e o diretor geral, Tom. Discutia-se sobre a demora na entrega das mercadorias aos clientes, tubos principalmente, e, em meio aos esclarecimentos dados e o compromisso afirmado por Jota de averiguar a causa desse problema, Dijalma traz o problema do faturamento, que poderia estar causando essa demora.

Nesse problema, cuja estrutura global encontra-se no Quadro 2, a seguir, é possível identificar uma estrutura mínima em relação à proposta por Patthey-Chavez (1994), constituída por duas fases: retomada e solução do problema.

Quadro 2 - Estrutura Global: Problema 1 - Faturamento

\begin{tabular}{|l|c|}
\hline \multicolumn{1}{|c|}{ Fases da Atividade } & \multicolumn{1}{|c|}{$\begin{array}{c}\text { Estrutura de } \\
\text { Participação }\end{array}$} \\
\hline $\begin{array}{l}\text { 1. Retomada do problema } \\
\text { Faturamento }\end{array}$ & $\begin{array}{c}\text { Dominância do } \\
\text { Representante de Vendas }\end{array}$ \\
\hline $\begin{array}{l}\text { 1.1. Sequência de esclarecimento } \\
\text { Procedimento administrativo }\end{array}$ & $\begin{array}{l}\text { Dominância do } \\
\text { Diretor Administrativo }\end{array}$ \\
\hline $\begin{array}{l}\text { 2. Solução do problema } \\
\text { Anotação no pedido (procedimento administrativo) }\end{array}$ & $\begin{array}{c}\text { Dominância do } \\
\text { Diretor Administrativo }\end{array}$ \\
\hline
\end{tabular}

(FONTE: Reunião com Representantes de Vendas 1; BASTOS, 2001),

No segmento 1, abaixo, relacionado ao problema do faturamento, veremos a atividade de fala relativa a esse problema. ${ }^{4}$

\footnotetext{
4 Os critérios de convenção de transcrição foram estabelecidos com base em Atkinson e Heritage (1984) e Tannen (1989), a saber: (.) entonação descendente ou final de enunciado; (,) entonação descendente de continuidade; ? entonação ascendente; = enunciados relacionados; (eh), hesitação, sinais de atenção ou pausa preenchida; (o:u) alongamento da vogal; (- - -) silabação; (..) pausa curta; (..) pausa longa; (I ) sobreposição de fala; ( ) fala não compreendida; (( )) comentário do analista, descrição de atividade não verbal; ("palavra”) fala relatada; (MAIÚSCULA) forte ênfase; (/.../) supressão de segmento.
} 
(1) Segmento 1: Problema 1 - Faturamento

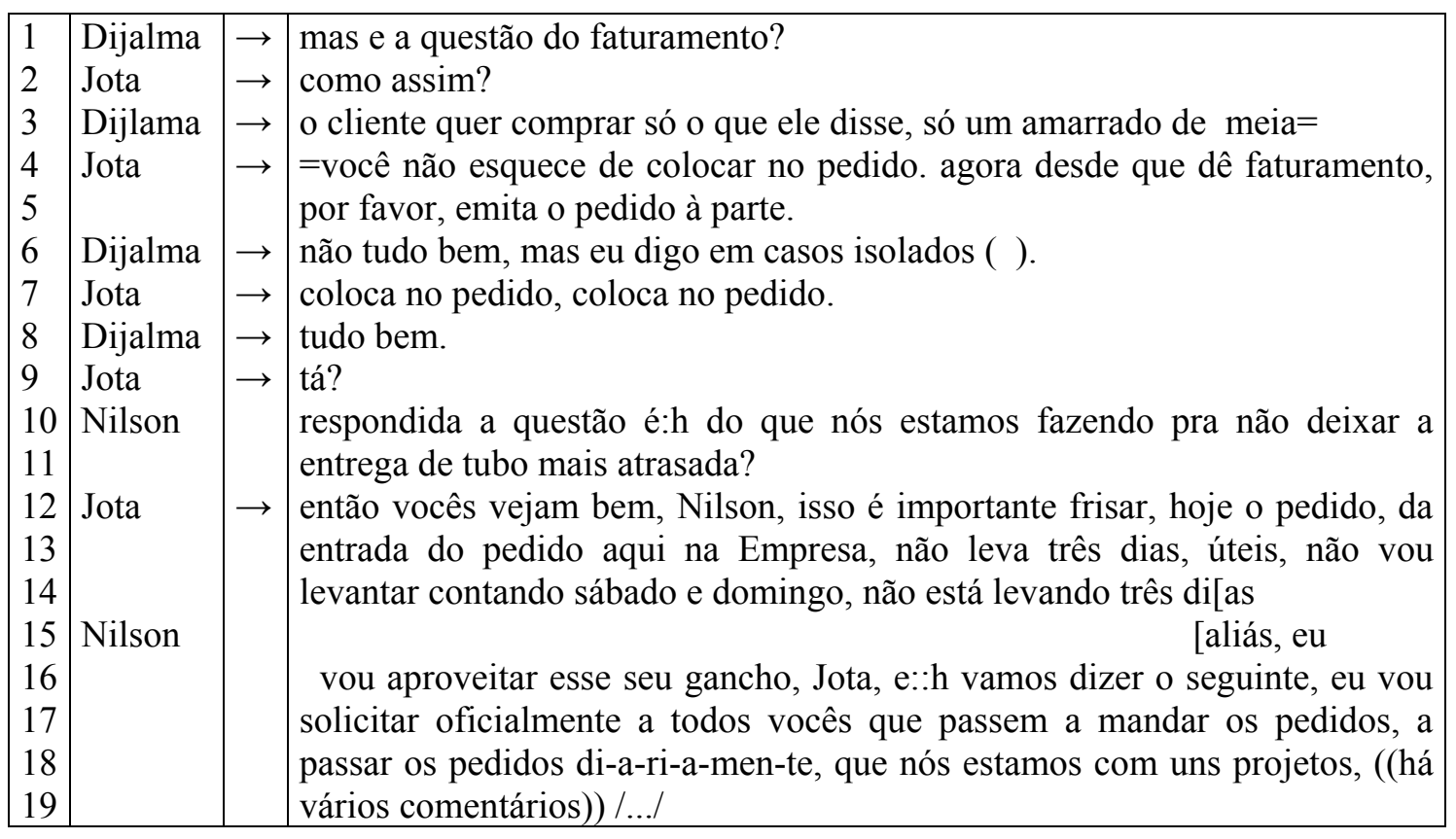

Dijalma introduz o problema com uma pergunta direta sobre o faturamento (1.1). Jota não entende a que se refere Dijalma e pede que este esclareça (1.2). Dijalma explica (1.3) e Jota orienta quanto ao procedimento a ser adotado (1.4-5), o que Dijalma demonstra saber "não tudo bem." (1.6). Observa-se, entretanto, que a orientação expressa ainda não dá uma resposta ao problema, que somente é explicitado quando Dijalma enuncia "mas eu digo em casos isolados." (1.6). Se para Dijalma o faturamento de tubos em "casos isolados" parece ser o problema, o mesmo não parece ser para Jota, que dá a solução rapidamente orientando o vendedor quanto a um segundo procedimento (1.7). Dijalma, por fim, expressa entender o que deve fazer (1.8). Nas linhas 12-14, Jota afirma que os pedidos de compras dos Representantes são atendidos no prazo máximo de três dias, fechando, assim, o problema da demora da entrega das mercadorias aos clientes.

Nessa interação, chama também à atenção a rápida sucessão de turnos breves, o que sugere certa animosidade, embora Jota pareça estar sintonizado com Dijalma pela fala engatada, entre as linhas 3 e 4 . Nesse sentido, a resposta de Jota, inclusive, nas linhas 4 e 5, contempla as duas situações relativas ao faturamento. Dijalma, entretanto, parece ter uma maior dificuldade para chegar ao cerne do problema, uma vez que este é explicitado somente após uma sequência de turnos e compartilhamento de informações.

Cabe ainda destacar que a solução dada consiste numa orientação de procedimento, originada, infere-se, de uma decisão anterior da empresa, a qual parece não ter sido compartilhada com todos os representantes comerciais. Este resultado é interessante, porque surge nas reuniões com os representantes de vendas em relação aos quais os gestores, em função do problema, propõem uma solução que já está prevista na rotina administrativa da empresa.

\subsection{Problema 2 - Embalagem}

O problema 2 em foco, Quadro 3 - Embalagem - é discutido na Reunião 2 com representantes comerciais. Dessa reunião participaram 11 profissionais: 8 representantes 
comerciais e os três gestores/líderes já citados: Nilson, Jota e Tom, o gerente de vendas, o diretor administrativo e o diretor geral, respectivamente.

O problema diz respeito à quantidade de itens que uma embalagem contém. Quanto maior a embalagem, ou seja, quanto maior o número de produtos numa mesma embalagem, há mais dificuldade para se vender o produto. Esse problema, entretanto, já está sendo resolvido pela Empresa. Vejamos a sua estrutura global.

Quadro 3 - Estrutura Global: Problema 2 - Embalagem

\begin{tabular}{|l|c|}
\hline \multicolumn{1}{|c|}{ Fases da atividade } & Estrutura de participação \\
\hline $\begin{array}{l}\text { 1. Comunicação problema, avaliação e diagnóstico } \\
\text { Embalagens grandes interferem na venda a clientes pequenos. }\end{array}$ & $\begin{array}{c}\text { Alternância do } \\
\text { Gerente de Vendas para } \\
\text { Representantes de Vendas }\end{array}$ \\
\hline 1.1. Pedido de esclarecimento & $\begin{array}{c}\text { Dominância do } \\
\text { Gerente de Vendas }\end{array}$ \\
\hline $\begin{array}{l}\text { 2. Antecipação de solução (esclarecimento) } \\
\text { Fracionamento prévio de embalagens }\end{array}$ & $\begin{array}{l}\text { Dominância do } \\
\text { Diretor Geral }\end{array}$ \\
\hline $\begin{array}{l}\text { 3.Proposta de solução } \\
\text { Divisão de outras embalagens }\end{array}$ & Multiparticipação \\
\hline $\begin{array}{l}\text { 4. Compromisso com a implementação de solução } \\
\text { Tentativa de fracionar mais um produto }\end{array}$ & Multiparticipação \\
\hline
\end{tabular}

(FONTE: Reunião com Representantes de Vendas 2, BASTOS 2001)

O Quadro 3, Problema 2 - Embalagem, acima, mostra as quatro fases de desenvolvimento da atividade de fala. Cabe observar agora que o representante de vendas, ao comunicar o problema, introduz também a avaliação e o diagnóstico. Observa-se a segunda fase, Antecipação de solução, que se refere a medidas que já vinham sendo tomadas pela empresa, antes do problema ser apresentado na reunião. Há ainda propostas de solução e, por último, o compromisso com a tentativa de implementar outras soluções.

A situação-problema a que se refere o representante de vendas Roque diz respeito à dificuldade de se vender embalagens grandes, isto é, com grande quantidade de produtos, uma vez que a área geográfica em que trabalha é composta por pequenos clientes. No segmento (2), encontra-se a sequência interacional relacionada ao Problema 2.

(2) Segmento 2: Problema 2 - Embalagem

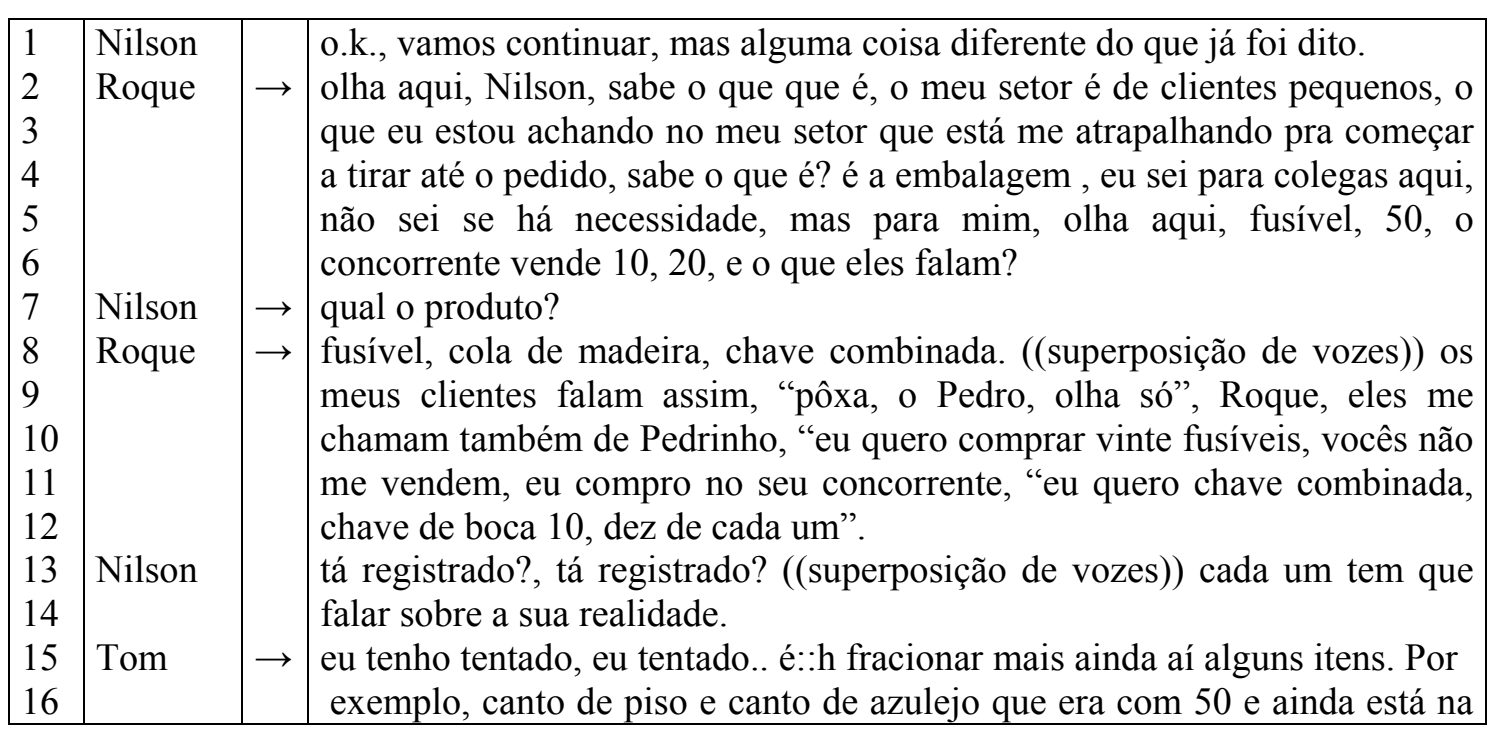




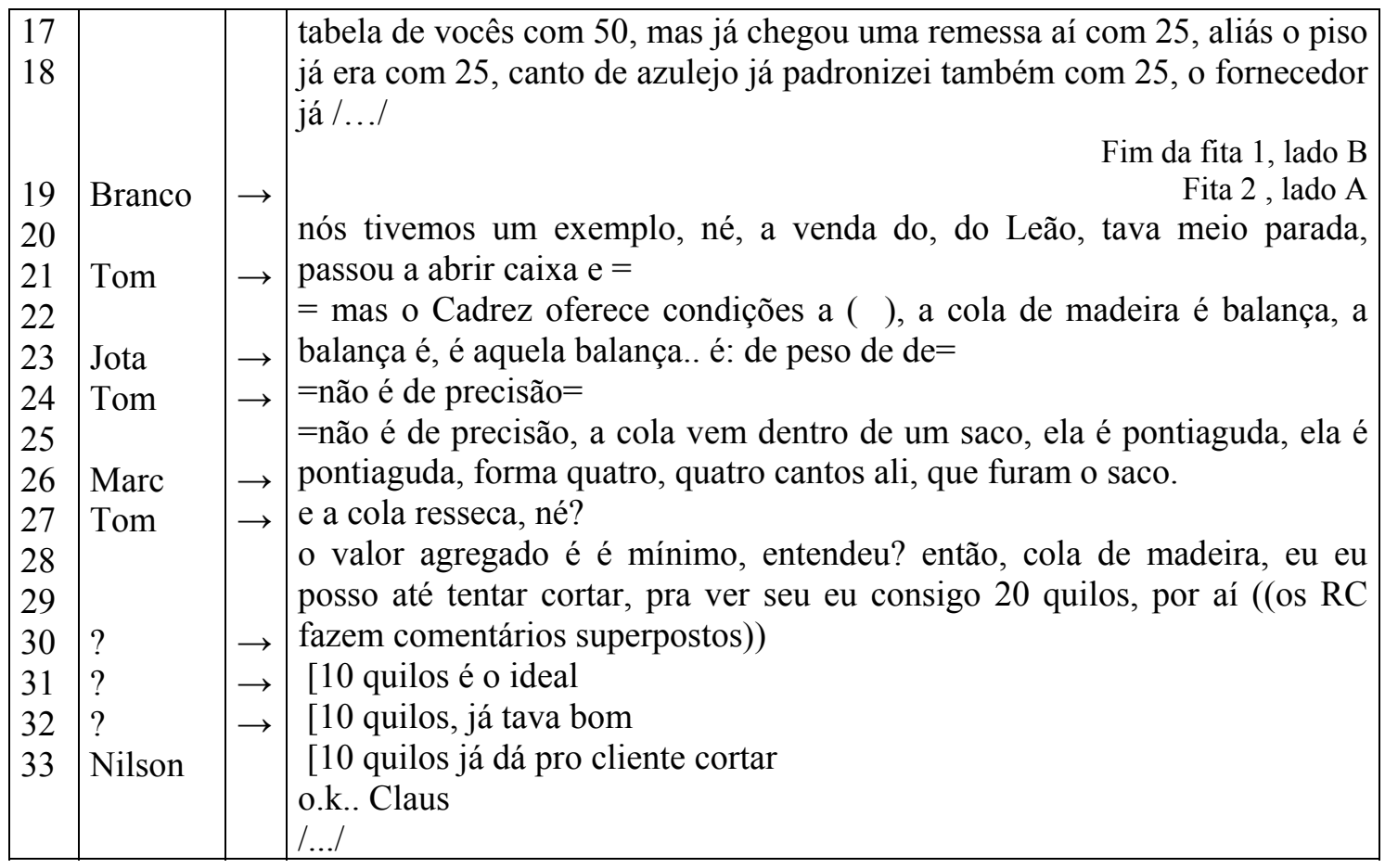

No segmento 2, acima, vemos que o representante de vendas Roque, dirigindo-se a Nilson, apresenta a situação-problema que se refere à dificuldade de se iniciar a venda, em função de a Empresa Ramo comercializar grandes embalagens, ao contrário dos concorrentes, fazendo também a avaliação e o diagnóstico (1s. 2-6). Observa-se o cuidado com que Roque apresenta a situação. Primeiro, ele caracteriza a área em que trabalha composta por "cliente pequenos" e, de forma mitigada, pelo uso do verbo modal "acho" e faz uma avaliação, relacionando essa característica da área ao tamanho da embalagem como o pr0blema para iniciar a venda "o que eu estou achando no meu setor que está me atrapalhando pra começar a tirar até o pedido, sabe o que é? é a embalagem". Em seguida faz uma ressalva em relação à necessidade dos colegas "eu sei para colegas aqui, não sei se há necessidade" e exemplifica o que fazem os correntes, especificando um produto, preparando para relatar a fala dos clientes "mas para mim, olha aqui, fusível, 50, o concorrente vende 10, 20". Apresenta, desse modo, uma possível solução para o problema. Nesse ponto, Nilson toma o turno, pedindo que Roque especifique o produto "Qual $o$ produto?" (1.7). Essa pergunta estratégica e a resposta dada por Roque acabam por evidenciar o problema e, consequentemente, a necessidade de uma solução por parte da empresa.

Roque passa, então, a detalhar a situação (ls. 8-12). Dá uma lista de produtos e traz à cena a voz do cliente, representando o problema no discurso de outro (BAKTHIN, 2002; TANNEN, 1989) " "pôxa, o Pedro, olha só', Roque, eles me chamam também de Pedrinho, 'eu quero comprar vinte fusíveis, vocês não me vendem, eu compro no seu concorrente, eu quero chave combinada, chave de boca 10, dez de cada um.' ". Embora Nilson pergunte se a contribuição dada está registrada (1.13), já que os representantes haviam preparado as respostas ao questionário entregue a eles antecipadamente, tendendo a encerrar essa atividade de fala, Tom dá continuidade, assumindo o turno. Informa estar tentando, através do fornecedor, fracionar alguns itens, mencionando outros que já estão em embalagens menores (ls.15-18). Ou seja, ele demonstra não apenas estar a par do problema, mas também apresenta as medidas que estão sendo tomadas para solucioná-lo. Tem-se, portanto, um reconhecimento da existência do problema, encapsulada na solução, que já vem sendo implementada pela Empresa, antes da exposição do problema na reunião. 
Em seguida, vários participantes constroem colaborativamente propostas de solução, contribuindo para que seja implementada uma solução mais adequada para o problema da embalagem. Branco relembra e sugere outro tipo de ação bem sucedida, referindo-se à abertura de uma caixa e à venda do produto (ls. 19-20); Tom, Jota e Marc passam a explicitar algumas condições favoráveis e desfavoráveis para se tomar algumas iniciativas (1s. 21-26); Tom compromete-se a tentar cortar a cola de madeira em $20 \mathrm{~kg}$ (1s. 27-28), configurando a tomada de decisão; e três representantes de vendas, em uníssono, sugerem o peso de $10 \mathrm{~kg}$ como a melhor solução para o corte da cola de madeira (ls. 30-32).

A habilidade de Roque na apresentação do problema envolve os demais participantes na busca da solução, evidenciada pelas sucessivas contribuições, pelas falas engatadas e pela afinação das vozes superpostas na sugestão final, enfatizando a proposta e conjuntamente suscitando um ambiente interacional cordial. Observa-se, também, mais uma vez que a estrutura global desse problema diferencia-se da estrutura prototípica, principalmente no que se refere à inserção de propostas de solução após a fase de compromisso de implementação da solução.

\subsection{Problema 3 - Atendimento ao cliente na janela}

O problema agora em evidência refere-se ao atendimento ao cliente na janela. Ocorre na reunião com operadoras de televendas. Desse encontro participam 6 profissionais: 3 operadoras de televendas, Nilson, Jota e Tom.

Faz-se notar a não linearidade dessa atividade de fala problema-solução, que ocorre em dois momentos distintos, $1^{\mathrm{a}}$ e $2^{\mathrm{a}}$ partes respectivamente. A estrutura global do problema 3 encontra-se, portanto, representada nos Quadros 4 e 5, a seguir:

Quadro 4 - Estrutura Global: Problema 3 - Atendimento ao cliente na janela (1 ${ }^{\text {a }}$ parte)

\begin{tabular}{|l|c|}
\hline \multicolumn{1}{|c|}{ Fases da Atividade } & Estrutura de Participação \\
\hline $\begin{array}{l}\text { 1. Comunicação do Problema } \\
\text { Interferência negativa no desempenho do trabalho de televendas } \\
\text { causada pelo cliente que vai à empresa sem pedido. As } \\
\text { Operadoras tem que parar o trabalho e atender o cliente. }\end{array}$ & $\begin{array}{c}\text { Alternância do } \\
\text { Gerente de Vendas para } \\
\text { Operadoras }\end{array}$ \\
\hline $\begin{array}{l}\text { 2. Diagnose/Avaliação } \\
\text { a) decisão: obrigação de atender o cliente } \\
\text { b) redefinição do problema: não há local para atendimento ao } \\
\text { cliente. }\end{array}$ & $\begin{array}{c}\text { Dominância do } \\
\text { Diretor Geral }\end{array}$ \\
\hline $\begin{array}{l}\text { c) avaliação da não interferência dos Representantes de Vendas } \\
\text { no trabalho de televendas }\end{array}$ & $\begin{array}{c}\text { Dominância do } \\
\text { Gerente de Vendas }\end{array}$ \\
\hline
\end{tabular}

(FONTE: Reunião de Televendas, BASTOS, 2001)

Quadro 5 - Estrutura Global: Problema 3 - Atendimento ao cliente na janela (2 ${ }^{\mathrm{a}}$ parte)

\begin{tabular}{|l|c|}
\hline \multicolumn{1}{|c|}{ Fases da Atividade } & Estrutura de Participação \\
\hline $\begin{array}{l}\text { 1. Retomada e avaliação do problema } \\
\text { Avaliação da situação de atendimento ao cliente na janela }\end{array}$ & $\begin{array}{c}\text { Dominância do } \\
\text { Diretor Geral }\end{array}$ \\
\hline $\begin{array}{l}\text { 2. Proposta de solução } \\
1^{\text {a }} \text {.) Aumento do Quadro de pessoal no Setor de Televendas }\end{array}$ & Multiparticipação \\
\hline $\begin{array}{l}2^{\mathrm{a}} \text {.) Oferecimento de um local adequado para atender o cliente } \\
\text { que vai à Empresa. }\end{array}$ & $\begin{array}{c}\text { Dominância do } \\
\text { Diretor Administrativo }\end{array}$ \\
\hline $\begin{array}{l}3^{\mathrm{a}} \text {.) Implantação de um sistema de rodízio para atendimento ao } \\
\text { cliente. }\end{array}$ & $\begin{array}{c}\text { Dominância do } \\
\text { Diretor Administrativo }\end{array}$ \\
\hline
\end{tabular}




\begin{tabular}{|l|c|}
\hline $\begin{array}{l}\text { 2.1 Esclarecimentos e oferecimento de benefícios e vantagens } \\
\text { para a aceitação do rodízio entre as Operadoras de Televendas } \\
\text { até a resposta final }\end{array}$ & Multiparticipação \\
\hline $\begin{array}{l}\text { 3. Compromisso com a implementação da solução } \\
\text { Preparação do local escolhido em comum acordo para } \\
\text { atendimento ao cliente }\end{array}$ & Multiparticipação \\
\hline
\end{tabular}

(FONTE: Reunião de Televendas, BASTOS, 2001)

Na estrutura global do Problema 3, Quadros 4 e 5, podem ser observadas todas as fases da atividade de fala problema-solução: da comunicação do problema ao compromisso com a implementação da solução.

O primeiro momento ( $\left(1^{\mathrm{a}}\right.$ parte) é desenvolvido logo após o resumo feito por Nilson aos Diretores Administrativo e Geral, até a sequência de avaliação da interferência dos representantes de vendas no trabalho de televendas. Após essa avaliação, é introduzido o problema da Troca de Mercadoria. Em seguida, é discutido outro problema relacionado à política de o cliente dirigir-se à empresa, se assim o desejar, para retirar a mercadoria comprada.

Vejamos como ocorre a organização da informação no terceiro problema evidenciado neste trabalho: Atendimento ao Cliente na Janela. No segmento 3, a seguir, encontraremos a comunicação do problema e a primeira sequência de diagnose e avaliação, conforme apresentado no Quadro 3. Terminando a recapitulação do que ocorrera nos quinze minutos iniciais, Nilson pergunta às operadoras de televendas - Sue, Joe e Isa - se elas têm mais alguma coisa a acrescentar. As contribuições dadas por elas serão compreendidas como problemas a serem resolvidos e, assim, iniciam-se as atividades de fala orientadas para a solução de problemas nessa reunião.

A pergunta é formulada dentro do enquadre de dúvida ou de necessidade de esclarecimento "mais alguma:: mais alguma:: dúvida ou necessidade de esclarecimento?" (1.1), ou seja, como término da primeira parte da reunião.

Atendendo à solicitação de Nilson, Joe apresenta um problema relacionado ao atendimento ao cliente na janela. Nilson procura identificá-lo, mantendo o enquadre da primeira parte do encontro, "levantamento de atividades", em que registra no flip-chart as tarefas realizadas pelas funcionárias (1.1-18). Tom intervém, dá um diagnóstico e faz um julgamento/avaliação sobre as condições operacionais da Empresa. Nilson, em seguida, procura avaliar a interferência dos representantes de vendas no trabalho do Televendas. A sequência interacional relacionada ao tratamento desse problema foi segmentada para fins de clareza. Vejamos:

(3) Segmento 3: Problema 3 - Atendimento ao cliente na janela ( $1^{\mathrm{a}}$ parte)

\begin{tabular}{|c|c|c|c|}
\hline $\begin{array}{l}2 \\
3 \\
4 \\
5 \\
6 \\
7 \\
8 \\
9\end{array}$ & $\begin{array}{l}\text { Sue } \\
\text { Joe } \\
\text { Sue }\end{array}$ & $\rightarrow$ & $\begin{array}{l}\text { uma:: mais alguma:: dúvida ou necessidade de esclarecimento? } \\
\text { son, nessa área aqui de atuação, entra também como venda, tá? } \\
\text { i, o nosso trabalho, né? essa segunda parte } \\
\text { trabalho, o trabalho de televendas. tem um ponto tá que a gente } \\
\text { a aí, a gente atende, mas pra gente chega, digamos assim, num é, a } \\
\text { certa pra gente não chega a ser atrapalhar } \\
\text { andamento do nosso serviço muitas vezes atrapalha. é o fato do } \\
\text { IIR à firma, SEM pedido aí ele chega do, da }\end{array}$ \\
\hline
\end{tabular}




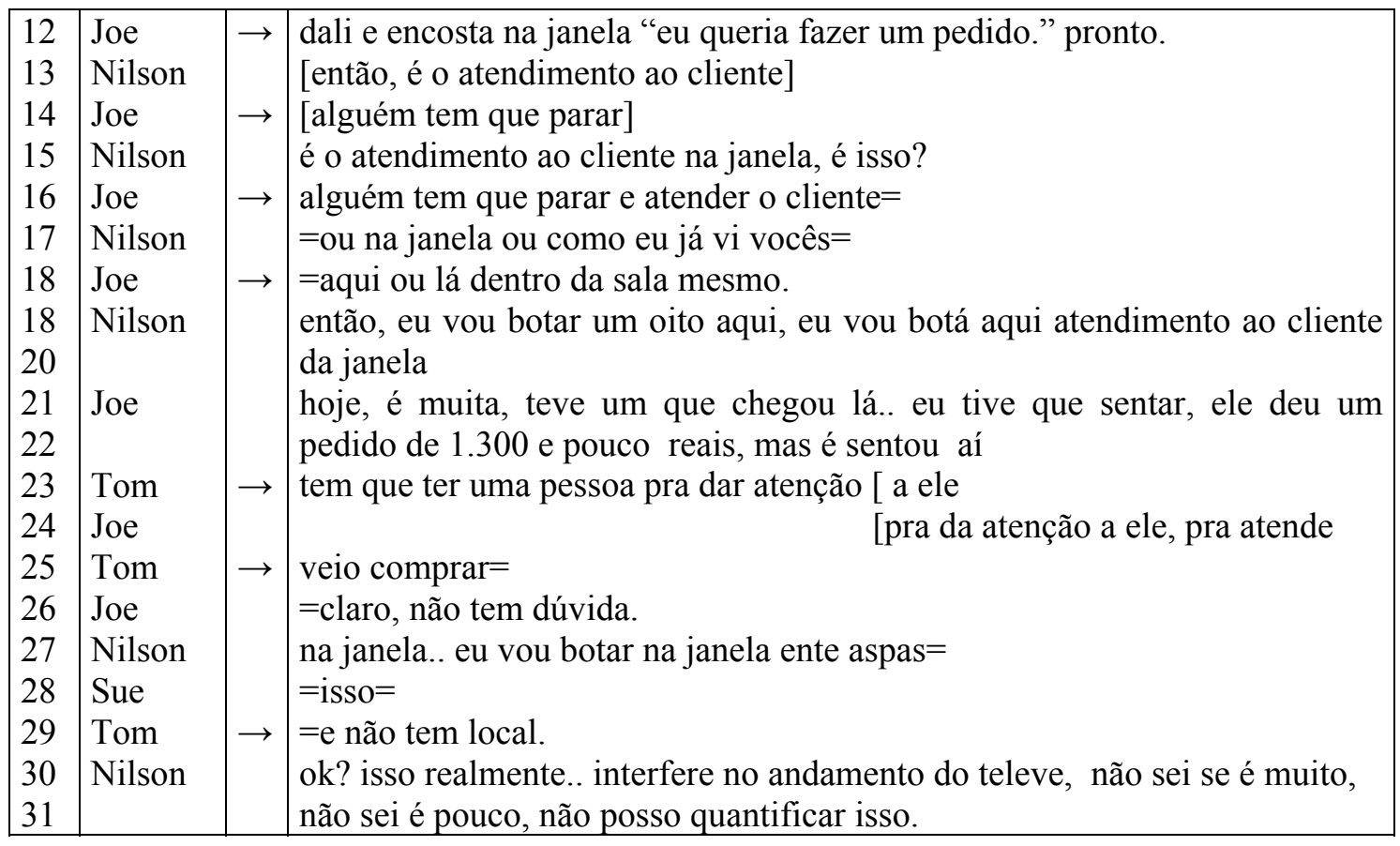

A resposta dada por Joe aponta para a situação-problema relacionada ao atendimento ao cliente que se dirige à empresa para comprar mercadoria, sem que este tenha feito previamente qualquer pedido de compra. Observe-se a cautela ao expor o problema, caracterizada por um adiamento nas linhas 5-9. Esse cliente se encosta à janela da sala do Setor de Televendas, e as Operadoras precisam interromper o trabalho para atendê-lo, o que, de certo modo, atrapalha o andamento das atividades. Joe, então, acentua as ações do cliente "mas pro andamento do nosso serviço muitas vezes atrapalha. é o fato do cliente VIR à firma, SEM pedido aí ele chega do, da", Sue completa "na janela" e Joe continua, encenando discursivamente a fala do cliente "dali e encosta na janela 'eu queria fazer um pedido’. pronto." (1s. 9-12).

Tom, o Diretor Geral, se auto-escolhe (1. 23), interrompe Joe e redefine o problema. Primeiro, profere uma decisão relacionada à obrigação de atender o cliente, deixando implícito o diagnóstico da não pertinência do problema apresentado: "tem que ter uma pessoa pra dar atenção a ele", "veio comprar" (1s. 23, 25). Observa-se que Joe afirmara ter vendido certa quantia em mercadorias (1. 21). A redefinição do problema ocorre em seguida, através da avaliação negativa das condições de trabalho da Empresa, que não tem local para atendimento ao cliente "e não tem local" (1.29). A falta de local adequado para atender o cliente passa, então, a ser o problema. Conforme Wagner (1995), as partes precisam concordar com a existência do problema para proporem soluções, o que será visto a partir da retomada do problema.

Se para Tom o problema reside no local de atendimento ao cliente, para Nilson o problema parece residir na interferência do atendimento ao cliente no trabalho de Televendas. Ou seja, cada gestor teria esquemas de conhecimento diferentes quanto às atividades a serem exercidas pelas Operadoras de Televendas. Observe-se que Nilson afirma não saber dimensionar o quanto o atendimento ao cliente na janela interfere no trabalho de televendas (1s. 30-31), realiza então perguntas dando início a uma sequência de esclarecimento, para avaliação, da interferência dos Representantes de Vendas (1s. 32-45), no segmento 3.1, abaixo, promovendo, em seguida, a mudança de tópico (ls. 44-45).

(4) Segmento 3.1: Problema 3 - Atendimento ao cliente na janela ( $1^{\mathrm{a}}$ parte) 


\begin{tabular}{|c|l|l|l|}
\hline 32 & Nilson & $\rightarrow$ & uma pergunta minha pra vocês: os vendedores, nossos representantes, \\
33 & Joe & & hum \\
34 & Nilson & $\rightarrow$ & têm ligado muito pra passar pedidos por telefone? \\
35 & Joe & & não, não têm não, ((todas concordam com Sue balançando a cabeça \\
36 & & & \\
& negativamente)) só em caso mesmo assim de urgência, ele sabe que tá \\
& montando uma carga, sabe? fora disso eles mesmo vem buscar aqui. \\
38 & Nilson & & não tem havido uma interferência como tem havido essa interferência da \\
39 & compra da janela, do atendimento da janela? \\
40 & Sue & $\rightarrow$ & não, não, o vendedor nesse ponto não, só em caso contrário, é de \\
41 & & necessidade ele sabe que tá sendo montado uma carga, ele não tem \\
42 & & condições de passar aí, ele passa por telefone. e a gente anota no pedido o \\
43 & & vendedor passou por telefone. \\
44 & Nilson & o.k. mais alguma, mais alguma situação que vocês passam, que vocês têm \\
45 & & atividades dentro da área de trabalho de vocês? surgiu mais uma agora. \\
\hline
\end{tabular}

Em resposta à última pergunta de Nilson (1.44-45), é introduzido o problema da troca de mercadoria. Conforme afirma Hoey $(1986 ; 1994)$, diante de uma avaliação negativa acerca de algo, o problema é reposto. Na medida em que não se chega a uma conclusão a respeito do local de atendimento ao cliente, a tendência é, portanto, a de se retornar ao problema. Nilson volta a ele cerca de 20 minutos depois.

O Problema 3 - Atendimento ao Cliente na Janela - é então retomado como se segue, segmento 3.2, e uma nova sequência de avaliação é feita, reiniciando-se o ciclo problema-solução.

(5) Segmento 3.2: Problema 3 - Atendimento ao cliente na janela ( $1^{\mathrm{a}}$ parte)

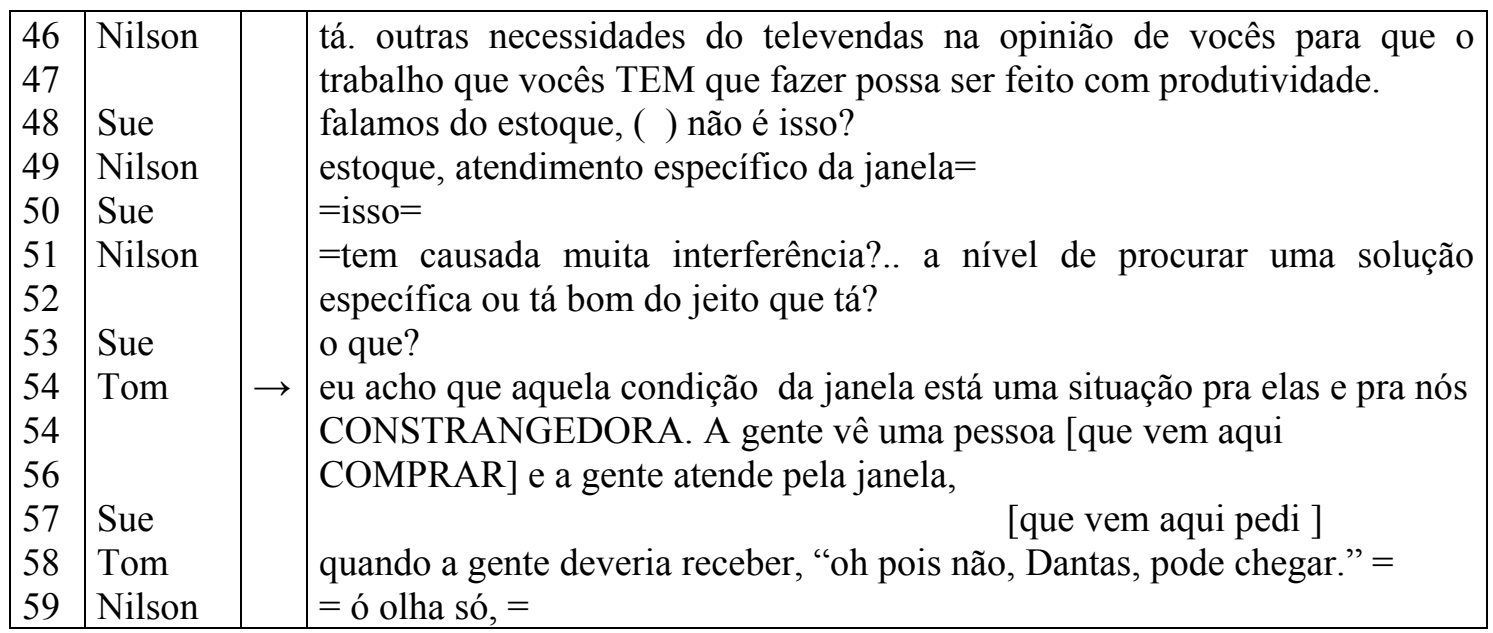

Nilson pergunta às Operadoras se o atendimento específico da janela tem causado muita interferência, a ponto de procurar uma solução específica ou se deve deixar do jeito que está (1.46; 51-52). Podemos observar, nessa sequência, que o Gerente afirma, mais uma vez, não saber dimensionar o quanto de interferência há no trabalho com esse tipo de atendimento. Outra vez, Tom se auto-escolhe e agora deixa clara a sua posição avaliativa sobre o local de atendimento $(1.54-56 ; 58)$. Na primeira sequência de avaliação, como exposto antes, ele havia dito que a Empresa não tinha local para atender o cliente. Nesse momento, ele avalia enfaticamente ser constrangedora a situação e sinaliza como se deve receber o cliente, construindo um diálogo "oh pois não, Dantas, pode chegar." (1.58) (TANNEN,1989). 
Dá-se início, então, o movimento de proposta de solução, terceira fase da atividade de fala. São feitas três propostas: $\left(1^{\mathrm{a}}\right)$ aumentar o quadro de pessoal do Setor de Televendas; $\left(2^{\mathrm{a}}\right)$ utilizar uma sala reservada para atender o cliente, e $\left(3^{\mathrm{a}}\right)$ estabelecer um sistema de rodízio entre as Operadoras de Televendas para a realização do trabalho. A seguir, no segmento 3.3 , pode ser vista a primeira proposta:

(6) Segmento 3.3: Problema 3 - Atendimento ao cliente na janela ( $2^{\mathrm{a}}$ parte)

\begin{tabular}{|c|c|c|c|}
\hline 60 & ota & & $=$ éh:: deixa eu aproveitar elas três aqui, deixa eu, $=$ \\
\hline 61 & Tom & & $=$ tá. \\
\hline 62 & Jota & & deixa eu fazer um sondagem, \\
\hline 63 & Sue & & $=$ hum. \\
\hline 64 & Jota & $\rightarrow$ & tá me ocorrendo uma idéia aqui? olha.. nós estamos, já discutimos o \\
\hline 65 & & & problema da janela, isso não é fato novo pra nós, tá? já detectamos, está em \\
\hline 66 & & $\rightarrow$ & fase final de implementação de alguma alternativa, tá. é o que que vocês \\
\hline 67 & & & me diriam de... o quadro ali vai ter que ser aumentado, isso é uma \\
\hline 68 & & $\rightarrow$ & necessidade, tá?.. é uma necessidade.. \\
\hline 69 & Nilson & & eu vou botar, eu vou botar isso aqui como uma necessidade, embora você \\
\hline 70 & & & não seja do t \\
\hline 71 & Jota & & $=$ ta bom $=$ \\
\hline 72 & Nilson & & =tá vendo uma necessidade. \\
\hline 73 & Jota & & é eu estou vendo e hoje eu fui alertado para essa necessidade $=$ \\
\hline 74 & Tom & & $=$ tem mais dua \\
\hline 75 & Jota & & $=$ a Rosa hoje me.. me deu um toque "o Jota, olha, as meninas lá estão \\
\hline 76 & & & sobrecarregadas. tem cliente que está esperando [MUITO] pra ser \\
\hline 77 & & & atendido" tá? \\
\hline 78 & Sue & & [é verdade] \\
\hline 79 & Jota & & clientes uns chegaram a reclamar, outros não reclamaram, mas a Rosa. tem \\
\hline 80 & & & alguma noção e pô ela fica assustada. tá ali esperando, tá esperando e não \\
\hline 8 & & & consegue a ligação, então o aumento do quadro é uma necessidade no meu \\
\hline 82 & & & ponto de $\mathrm{v}$ \\
\hline 83 & Sue & & $=\mathrm{e}$ inclusive esse seria o nosso próximo assunto agora, né? \\
\hline
\end{tabular}

Jota, o diretor administrativo, assume o turno com um pedido de licença, com o que Tom concorda, e justifica a tomada de turno "tá me ocorrendo aqui uma ideia" (1.64), propondo realizar uma "sondagem". Suspende a sondagem "o que que vocês me diriam de..." e formula a primeira proposta de solução que consiste em aumentar o quadro de funcionárias do Setor de Televendas "o quadro ali vai ter que ser aumentado, isso é uma necessidade, tá?, isso é uma necessidade."(1.67-68), trazendo com testemunho a voz da telefonista Rosa "=a Rosa hoje me.. me deu um toque 'o Jota, olha, as meninas lá estão sobrecarregadas. tem cliente que está esperando [MUITO] pra ser atendido"' (1s.75-77). Essa proposta, construída com a concordância dos participantes, será aceita por todos, configurando a primeira solução dada e a primeira decisão.

A segunda e terceira propostas constituem a sondagem enunciada anteriormente. A aceitação depende agora das operadoras de televendas. Da formulação das propostas à sua aceitação, esclarecimentos são pedidos e dados, e benefícios e vantagens são oferecidos. A título de clareza, segmentamos essa fase da atividade de fala em sequências menores, de 3.4 a 3.7. O segmento de fala 3.4, a seguir, refere-se às propostas e ao pedido de esclarecimento.

(7) Segmento 3.4: Problema 3 - Atendimento ao cliente na janela ( $2^{\mathrm{a}}$ parte) 


\begin{tabular}{|c|c|c|c|}
\hline 84 & Jota & $\rightarrow$ & então o que que vocês, o trabalho é de equipe, \\
\hline 85 & Sue & & claro. \\
\hline 86 & Nilson & & o trabalho é de equipe. \\
\hline 87 & Jota & & certo? \\
\hline 88 & Nilson & & dentro de trabalho [tem um série de tarefas] \\
\hline 89 & Jota & $\rightarrow$ & [pra eu pegar..], pra eu pegar uma pessoa nova, tá, de \\
\hline 90 & & & fora, pra implementar o atendimento lá.. no na ponta da linha lá no junto \\
\hline 91 & & & ao cliente que chega aqui, $=$ \\
\hline 92 & Sue & & $=$ certo $=$ \\
\hline 93 & Jota & & $=$ pra acabá a janela, $=$ \\
\hline 94 & Sue & & $=$ hum $=$ \\
\hline 95 & Jota & $\rightarrow$ & =tá, eu provavelmente eu vou ter que.. ter uma pessoa tarimbada.., tá? eu \\
\hline 96 & & & vou colocá-la ((apontando para Isa)) que já tem dois meses, está muito \\
\hline 97 & & & melhor que uma pessoa crua que não conhece nada da nossa empresa, nem \\
\hline 98 & & & da nossa realidade, tá? o que que vocês me diriam de eu montar lá dentro,= \\
\hline 99 & Sue & & $=$ hum? \\
\hline 100 & Jota & $\rightarrow$ & tá? eu tenho uma sala ali, totalmente reservada, eu montar com vocês um \\
\hline 101 & & & rodízio, cada uma até atender os telefones lá e ao mesmo tempo atender \\
\hline 102 & & & alguns clientes que viessem aqui? acabar com a janela. que que vocês \\
\hline 103 & & & acham da idéia? \\
\hline 104 & Sue & & faríamos um rodízio? \\
\hline 105 & Joe & & mas esse rodízio assim.. quem estivesse lá, atenderia as ligações daqui \\
\hline 106 & & & também do televendas? \\
\hline 107 & Jota & & até poderia atender, até poderia atender. como? "Rosa, olha não estou com \\
\hline 108 & & & cliente nenhum aqui, ligação pode passar pra mim, também. \\
\hline
\end{tabular}

Jota primeiro faz uma preparação em que procura despertar o sentimento de equipe e valorizar a experiência das funcionárias (1.84-95), o que vai sendo acompanhado atentamente por Sue, Joe e Isa, para então formular as propostas para acabar com o atendimento da janela "eu tenho uma sala ali, totalmente reservada, eu montar com vocês um rodízio, cada uma até atender os telefones lá e ao mesmo tempo atender alguns clientes que viessem aqui? acabar com a janela." (1s. 100-103), solicitando, em seguida, que elas se posicionem "que que vocês acham da ideia?" (1. 102-103). Sue faz uma pergunta de confirmação e Joe uma pergunta de esclarecimento (1.104-106). Jota admite a possibilidade de elas atuarem nas duas atividades - televendas e atendimento ao cliente durante o rodízio e demonstra como proceder através de um diálogo construído (1.107108).

O segmento relativo a esclarecimentos e oferecimento de benefícios e vantagens para a aceitação do rodízio entre as Operadoras de Televendas, realizado em quinze turnos, foi omitido aqui. Finalizando, no movimento abaixo, segmento 3.5, as operadoras expressam a concordância com a proposta feita.

(8) Segmento 3.5: Problema 3 - Atendimento ao cliente na janela ( $2^{\mathrm{a}}$ parte)

\begin{tabular}{|c|c|c|c|}
\hline 127 & Sue & $\rightarrow$ & por mim tudo bem, Jota, a princípio $=$ \\
\hline 128 & Joe & $\rightarrow$ & $=$ eu acho até necessário até que tenha, que tenha= \\
\hline 129 & Jota & $\rightarrow$ & $=$ por que? pra eu colocar uma pessoa novata, crua $=$ \\
\hline 130 & Tom & & mas nós já falamos, você já falou que ia colocar uma pessoa lá. \\
\hline 131 & Jota & & é::h Tom, mas a dificuldade que eu não tinha me ocorrido, que está me \\
\hline 132 & & & ocorrendo agora, seria eu aproveitar o know-how que elas já têm. \\
\hline 133 & Tom & & você coloca duas ou três junto com elas ali, que elas vão se treinando ali. \\
\hline 134 & Jota & & enquanto isso o tempo e quem vai ficar lá? \\
\hline
\end{tabular}




\begin{tabular}{|c|c|c|}
\hline $\begin{array}{l}135 \\
136 \\
137\end{array}$ & $\begin{array}{l}\text { Tom } \\
\text { Jota } \\
\text { Joe }\end{array}$ & $\begin{array}{l}\text { não, vai, elas vão rolando as três }= \\
=\text { ah, certo.. um rodízio, aí sim }= \\
=\text { porque realmente tem que ter alguém lá, porque isso é= }\end{array}$ \\
\hline
\end{tabular}

A aceitação da proposta é construída colaborativamente por Sue, Joe e Jota (1s. 127129, seguindo-se a isso uma sequência de esclarecimento entre Tom e Jota (1s. 130-136) É tomada a segunda decisão. Passa-se, assim, à quarta fase da atividade de fala - o compromisso de implementação das decisões em que são propostos modos de implementar as decisões tomadas. Nessa fase, apenas a decisão relacionada ao local de atendimento é contemplada, embora outras ações comunicativas também ocorram. Essa fase é ilustrada pelos segmentos 3.6 e 3.7 .

Jota já mencionara que havia uma sala totalmente reservada para o atendimento ao cliente. Tom, no entanto, propõe que o atendimento seja feito ali mesmo, no Setor de Televendas, sugerindo certa mudança no ambiente físico, insistindo diante das avaliações negativas de Jota (1s. 138-143), conforme pode ser visto no segmento 3.6.

(9) Segmento 3.6: Problema 3 - Atendimento ao cliente na janela ( $2^{\mathrm{a}}$ parte)

\begin{tabular}{|c|c|c|c|}
\hline 138 & Tom & $\rightarrow$ & $=$ e se desse atendimento aqui ao cliente, aqui no televendas é muito ruim? \\
\hline 139 & Jota & $\rightarrow$ & é ruim. \\
\hline 140 & Tom & $\rightarrow$ & ali, uma mesinha ali do lado, nós já tínhamos falado até, uma mesa ali do \\
\hline 141 & Jota & $\rightarrow$ & lado \\
\hline 142 & Tom & $\rightarrow$ & eu acho pior, eu acho pior. \\
\hline 143 & Jota & $\rightarrow$ & rasgava até uma porta pro cliente. \\
\hline 144 & Joe & & eu, na minha opinião, seria melhor uma pessoa lá[.. ]entendeu? \\
\hline 145 & Nilson & $\rightarrow$ & [é] \\
\hline 146 & Joe & $\rightarrow$ & o cliente encaminhado.. pra lá $=$ \\
\hline 147 & Jota & $\rightarrow$ & $=$ veio sem pedido $=$ \\
\hline 148 & Joe & $\rightarrow$ & $=[$ pra lá $]$ \\
\hline 149 & Nilson & $\rightarrow$ & $=[$ prá lá $]=$ \\
\hline 150 & Jota & $\rightarrow$ & $=$ não veio com pedido ou sem pedido.. lá= \\
\hline 151 & Nilson & $\rightarrow$ & $=$ porque tudo que acontece vem parar aqui $=$ \\
\hline 152 & Jota & $\rightarrow$ & $=$ vem buscar tudo lá= \\
\hline 153 & Tom & $\rightarrow$ & $=$ ah eu queria fazer uns acréscimos, aí o cliente volta pra cá. \\
\hline 154 & & & bota logo essa gente aí, bota essas moças logo, que eu, eu eu realmente: \\
\hline 155 & & & eu tou aflito com essa situação do cliente vindo na janela, ah isso me \\
\hline 156 & & & aflige... eu.. \\
\hline 157 & Nilson & & ((vira a folha do flip-chart)) aumento do quadro. \\
\hline 158 & Tom & $\rightarrow$ & t[em que botar uma moça, tem que botar uma moça, vai botando] \\
\hline 159 & Nilson & $\rightarrow$ & [é::h atendimento especifico, eu coloquei as duas coisas aqui..] outras \\
\hline 160 & & $\rightarrow$ & necessidades. \\
\hline 161 & Jota & & vocês vão amadurecer isso aí, ou vocês.. veem alguma dificuldade? \\
\hline 162 & Sue & $\rightarrow$ & nã::o, acho que tudo é válido. \\
\hline 163 & Jota & $\rightarrow$ & vocês são quatro, no máximo cada dia uma ((vozes superpostas)) \\
\hline 164 & & & é bom, sem dúvida. \\
\hline 165 & Tom & & muda o ambiente de trabalho sai dali mesa, sai da sala, vai pra lá, \\
\hline 166 & & & conversa,$=$ \\
\hline 167 & Nilson & & $=0$ cliente sempre fala, sempre conhece outras pessoas, sempre distrai um \\
\hline 168 & & & pouco.. acho que é válido. ( ) outras necessidades? \\
\hline
\end{tabular}

Todos os participantes recusam a proposta de Tom. Chama a atenção a união entre eles, emitida em fina sintonia pelas falas engatadas, superposições colaborativas, pelo 
ritmo e, até, pela rima. Diante disso,Tom, mudando o alinhamento (GOFFMAN, 1981), dá uma ordem clara e direta a Jota parecendo exasperado, perceptível pelo exame das escolhas lexicais e sintáticas, talvez por ter tido a sua proposta recusada por todos do modo como o foi "bota logo essa gente aí, bota essas moças logo, que eu, eu eu realmente: "eu tou aflito com essa situação do cliente vindo na janela, ah isso me aflige... eu.." (1.153-156); "t[em que botar uma moça, tem que botar uma moça, vai botando]"(1. 158). Nilson voltase para o registro no flipchart. Jota, por sua vez, aparentemente impermeável à ordem de Jota procura estabelecer um chão comum com as operadoras, desejando saber se elas precisam de tempo para amadurecer a ideia e refletir sobre alguma dificuldade "vocês vão amadurecer isso aí, ou vocês.. veem alguma dificuldade?’(1. 161). A partir daí, os participantes passam a concordar com a decisão tomada. Tom, agora, mudando o alinhamento, dirige-se a elas, procurando mostrar as vantagens da alternância do local de trabalho em apoio a Jota (1s.165-166). Nilson também colabora e procura mudar o tópico.

Concluindo a quarta fase da atividade de fala, Jota faz a última proposta relacionada ao local de atendimento, apresentada na sequência 3.7. Vejamos.

(10) Segmento 3.7: Problema 3 - Atendimento ao cliente na janela ( $2^{\mathrm{a}}$ parte)

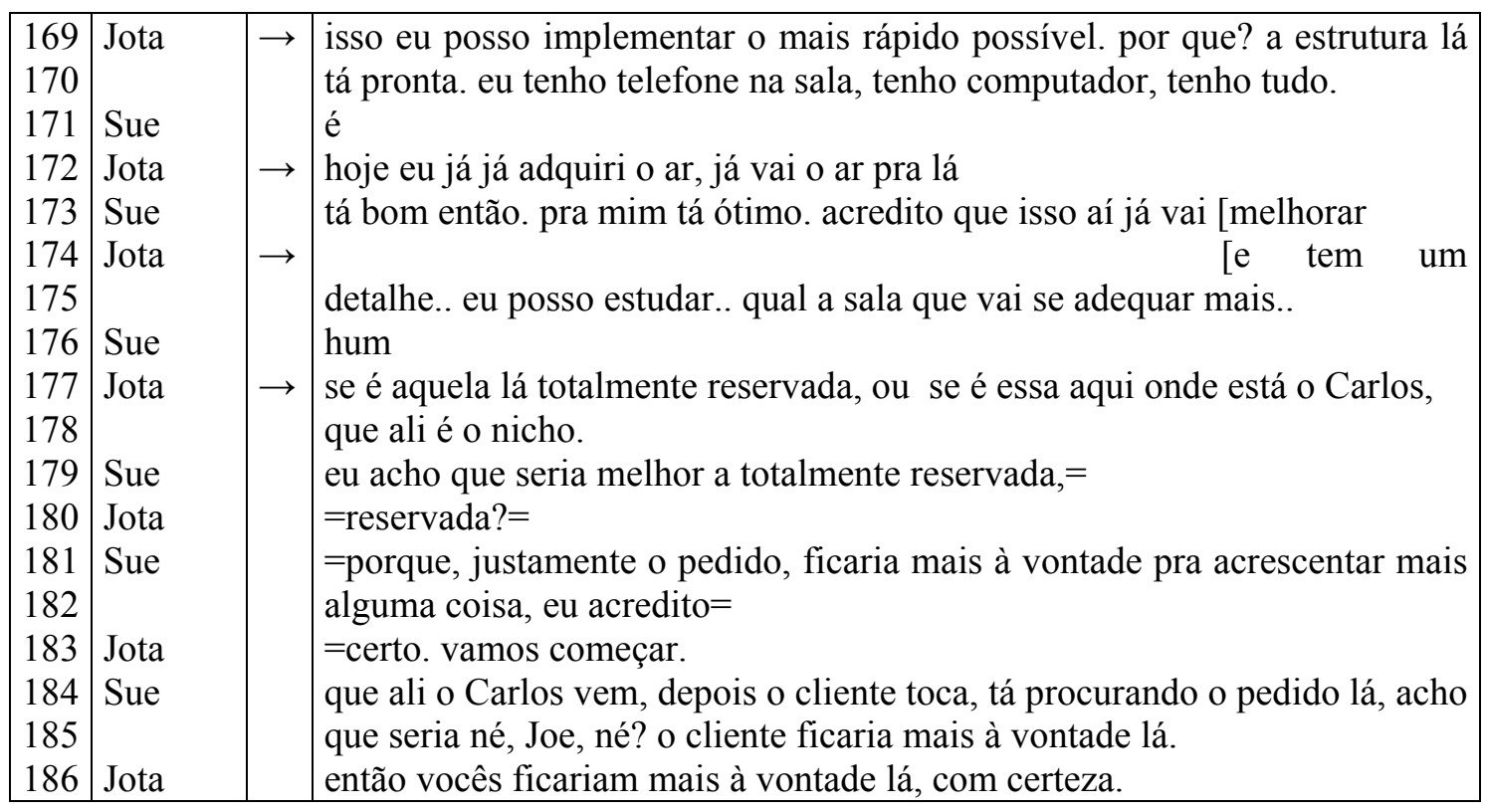

Primeiro, Jota afirma poder agilizar o que fora ali decidido, uma vez que a estrutura necessária para isso está quase pronta $(1.169-170 ; 172)$; segundo, ele propõe decidir sobre a sala mais adequada entre duas alternativas expressas $(1.175,177)$. Sue, que manifestava concordância, faz, nesse momento, a escolha da sala "eu acho que seria melhor a totalmente reservada, =" (1.179), justificando-a "porque, justamente o pedido, ficaria mais à vontade pra acrescentar mais alguma coisa, eu acredito="(1s.181-182); "que ali o Carlos vem, depois o cliente toca, tá procurando o pedido lá, acho que seria né, Joe, né? o cliente ficaria mais à vontade lá".(1. 184-185). Jota concorda com a escolha feita, assumindo com as Operadoras o compromisso de implementar última decisão conjuntamente tomada: "então vocês ficariam mais à vontade lá, com certeza" (1.186).

Observamos que sua estrutura global diferencia-se da estrutura prototípica, na medida em que, na última fase, temos um compromisso com a implementação da solução. Embora a estrutura global proposta possa organizar as informações em fases, ela não reflete a complexidade e a riqueza da dinâmica interacional. 


\section{Conclusões}

A análise das atividades de fala problema-solução revela que o modelo proposto por Patthey-Chavez (1994), embora preveja uma organização linear para o desenvolvimento das fases que o constituem, não captura e não reflete a complexidade do processo de co-construção dessa atividade em reuniões de multiparticipação, salvo poucos casos. Acresce-se ainda que esse modelo não pode ser generalizado para todos os casos de solução de problema.

Observa-se que estruturas mais desenvolvidas são construídas na reunião com o Setor de Televendas, uma vez que os problemas ali discutidos estão restritos a questões julgadas como internas à empresa. É importante observar que as situações-problema, nessa reunião, tendem a ser tratadas em dois momentos distintos. No primeiro momento, o problema ou é suspenso ou é considerado como não existente. É, depois, então retomado ou recolocado e outra sequência é desenvolvida, conforme vimos no problema 3 Atendimento ao cliente na janela.

As situações apresentadas pelos colaboradores geralmente são introduzidas por solicitação dos gestores/líderes a título de dúvida ou de necessidade de esclarecimento, ou a título de sugestões visando a melhores resultados nos negócios. A contribuição dada pode ser ou não tratada como problema, ou um problema pode ser (re)definido a partir da contribuição. Nesse sentido, pode haver várias sequências de avaliação e diagnóstico para um mesmo problema. É interessante observar, também, que uma decisão expressa pode encapsular uma avaliação e levar a um diagnóstico, como ilustra a primeira parte do Problema 3. Avaliações e diagnósticos geralmente são dados pelos gestores/líderes, embora os colaboradores também possam trazer junto às contribuições suas próprias avaliações, o que é mais evidente nas reuniões com os Representantes de Vendas. Havendo o reconhecimento ou a identificação da(s) causa(s) de um problema, consensualmente ou não, propostas de solução são dadas, geralmente pelos gestores/líderes.

Quanto à fase de compromisso com a implementação de solução, são assumidos compromissos de implementação de decisões tomadas ou de estudo futuro de uma solução adequada. Essa fase, comumente iniciada por um líder/gestor, tende à multiparticipação. Cabe ainda notar que pedidos de esclarecimento, geralmente formulados pelos gestores/líderes, podem ser inseridos em diferentes momentos na sequência problemasolução

Tem-se, assim, que, para se tratar de um problema, os participantes têm que realizar certas ações: (a) concordar que há um problema, (b) encontrar uma solução e/ou (c) dar uma avaliação ou diagnóstico. Para isso, os participantes precisam interagir sobre certos tópicos e não, necessariamente, concordar sobre o problema. A construção dessa atividade está sujeito a relevantes fatores contextuais, inclusive em relação aos propósitos da interação, aos papéis interacionais e institucionais dos profissionais, que tendem a dar contribuições a partir das suas áreas de especificidade e da provisão de informação que detêm, e da necessidade de dar prosseguimento ou não a uma fase da sequência das atividades de fala, enfim, dos procedimentos socialmente compartilhados, realizados local e situacionalmente.

No que se refere à participação dos profissionais, observa-se que cada uma das fases da sequência constitui tipicamente um "território", embora não exclusivo, dos participantes. Operadoras de Televendas e Representantes de Vendas apresentam a situação-problema, a princípio como planejado pelo coordenador da reunião. Os gestores/líderes surgem dominantes nas fases de avaliação e diagnósticos na Reunião de Televendas; nas reuniões com os Representantes de Vendas, observa-se uma tendência à 
multiparticipação. As fases de propostas de solução e compromisso de implementação de solução tendem a uma estrutura de multiparticipação, no sentido de que, geralmente, são iniciadas pelos gestores/líderes e outras vozes se inserem na co-construção dessas fases. As sequências de esclarecimento, que podem ocorrer entre as fases previstas na estrutura, via de regra são solicitadas pelos gestores/líderes.

Variações, no entanto, ocorrem. O problema pode ser retomado ou recolocado por qualquer participante. Além disso, os Representantes de Vendas, ao colocarem o problema, geralmente apresentam uma avaliação e uma sugestão de solução, sobre as quais incidem uma avaliação e/ou um diagnóstico dos líderes-gestores. Diagnose e avaliação e propostas de solução também podem ser dados em multiparticipação. Compromissos podem ser assumidos coletivamente. Cada tipo de problema, entretanto, pede um tipo de solução diferenciada. E o compromisso com a implementação de uma solução definitiva ou é afirmado ou é assumido o estudo de possíveis soluções. Quanto às tomadas de decisões, observa-se, nas reuniões com os Representantes Comerciais, que decisões para a solução dos problemas apresentados ou estavam previstas na rotina administrativa ou já vinham sendo tomadas previamente, surgindo também a possibilidade de se ampliar as ações . Já nas reuniões com as Operadoras de Televendas, é possível observar a decisão emergir na atividade em fases distintas.

Se, por um lado, o processo de solução de problemas em reunião de multiparticipação possa ser proveitoso e vantajoso para gestores/líderes e colaboradores, levando ao compartilhamento dos problemas e a construção colaborativa em diversas momentos dessa atividade, por outro lado, foi possível notar que, nesse processo, se refletiu a estrutura hierárquica da empresa, evidenciando a assimetria de poder entre os participantes, a cordialidade e tensões durante o processo.

Relacionados à questão da participação dos profissionais no processo de solução de problemas, encontram-se a distribuição do conhecimento, o modo como é interpretado por diferentes profissionais, dependendo do seu acesso ao conhecimento, à autoridade e à responsabilidade e à qualidade no relacionamento. Convidados a participar de reuniões que se propõem a fazer uma ampla avaliação das atividades de vendas, percebe-se que todos os participantes podem contribuir com conhecimentos específicos e complementar uns aos outros na construção de um conhecimento compartilhado para esclarecimento e busca de solução de problemas e tomadas de decisão.

\section{REFERÊNCIAS}

BAKTHIN, M. Marxismo e filosofia da linguagem: problemas fundamentais do método sociológico na ciência da linguagem. Tradução de Michel Lahud e Yara Frateschi Vieira. 10.ed. São Paulo: Hucitec, 2002.

BASTOS, C. R. P. Estilos discursivos de liderança gerencial em atividades de fala problema-solução em reuniões empresariais. 2001. Tese (Doutorado em Letras)-Pontifícia Universidade Católica, Rio de Janeiro, 2001.

BELMONTE, I. A. Toward a genre-based characterization of the problem-solution textual pattern in English newspaper editorials and op-eds. Text \& Talk - An Interdisciplinary Journal of Language, Discourse \& Communication Studies. v. 29, n. 4, p.393-414, july 2009. 
BODEN, D. The business of talk. Cambridge: Polity Press, 1994.

ERICKSON, F.; SCHULTZ, J. O quando de um contexto: questões e métodos na análise da competência social. Tradução Pedro M. Garcez e Clarissa Surek-Clark. In: RIBEIRO, B. T.; GARCEZ P. M. (Org.). Sociolingüística interacional: antropologia, linguística e sociologia em análise do discurso. Porto Alegre, AGE, 2002. p. 215-153

GOFFMAN, E. Footing. In: GOFFMAN, E. Forms of talk. Philadelphia: University of Pennsylvania Press, 1981.

GUMPERZ, J. J. Discourse strategies. Cambridge: Cambridge University Press, 1982.

HOEY, M. Overlapping patterns of discourse Organization and Their Implications for Clause Relational Analysis of Problem-Solution Texts. In COOPER, C. R.; GREENBAUN, Sidney (Eds). Studying Written: Linguistic Approaches. USA, Sage Publications, 1986. p.187-214

HOEY, M.. Signalling in discourse: a functional analysis of a common discourse pattern in written and spoken English. In: COULHARD, Malcolm (Ed.) Advances in written text analysis. London; New York: Routledge, 1994. p. 27-45

HYMES, D. Foundations in sociolinguistics: an ethnographic approach. London, Tavistock, [1974] 1977.

KUHN, T.; JACKSON, M. H. Accomplishing knowledge:a framework for investigating knowing in organizations. Management Communication Quarterly, v.21, n.4. p.454-485, may 2008, p.454-485.

LIMA, F. O.; TEIXEIRA, P. C. Direcionamento estratégico e gestão de pessoas nas organizações. São Paulo: Atlas, 2000.

LINNEL, P.; LUCKMAN, T. Asymmetries in dialogue: some conceptual preliminaries. In MARKOVÁ, I.; FOPPA, K. (Ed.). Asymmetries in Dialogue. Harvset Wheastsheaf, London: Barnes; United Stades: Noble Books,1991. p.1-20

PATTHEY-CHAVEZ, G. G. Producing the authoritative voice in a computer lab. Text 14, n.1, p.77-111, jan., 1994.

PEREIRA, M. G. Interações de ajuda em um serviço de atendimento ao cliente em uma empresa brasileira. In: CONFERÊNCIA INTERNACIONAL DE PRAGMÁTICA, 5., Anais..., México, 1996.

SACKS, H.; SCHEGLOFF, E. A.; JEFFERSON, G. A simplest systematic for the organization of turn-taking for conversation. Language v. 50, n.4, p.696-735, dec., 1974.

SARANGI, S.; ROBERTS, C. (Ed). Talk, work and institutional order: discourse in medical, mediation and management settings. Berlin; New York: Mouton Gruyter, 1999.

SCHIFFRIN, D. Discourse markers. Cambridge: University Press, 1996.

TANNEN D.; WALLET, C. Interactive frames and knowledge schemas in interaction: examples from a medical examination/interview. Social Psychology Quarterly, v. 50, n. 2, p. 205-216, jun., 1987.

TANNEN, D. Talking Voices: repetition, dialogue and imagery in conversational discourse. Cambridge: Cambridge University, Press, 1989. 
WAGNER, J. 'Negotiating Activity' in Technical Problem Solving. In: FIRTH, Alan (ed.) The discourse of negotiation. Studies of language in the workplace. Pergamon, Dinamarca, 1995. p. 223-245.

Recebido em fevereiro de 2013.

Aprovado em abril de 2013. 